\title{
Impact of progressive global warming on the global-scale yield of maize and soybean
}

\author{
Gillian Rose $^{1,2}$ - Tom Osborne ${ }^{3} \cdot$ Helen Greatrex ${ }^{4}$. \\ Tim Wheeler ${ }^{1,2}$
}

Received: 2 June 2014 / Accepted: 6 January 2016 / Published online: 10 February 2016

(C) The Author(s) 2016. This article is published with open access at Springerlink.com

\begin{abstract}
Global surface temperature is projected to warm over the coming decades, with regional differences expected in temperature change, rainfall and the frequency of extreme events. Temperature is a major determinant of crop growth and development, affecting planting date, growing season length and yield. We investigated the effects of increments of mean global temperature warming from $0.5{ }^{\circ} \mathrm{C}$ to $4{ }^{\circ} \mathrm{C}$ on soybean and maize development and yield, both globally and for the main producing countries, and simulated adaptation through changing planting date and variety. Increasing temperature resulted in reduced growing season lengths and ultimately reduced yields for both crops. The global yield for maize decreased as temperature increased, although the severity of the decrease was dependent on geographic region. Small temperature increases of $0.5^{\circ} \mathrm{C}$ had no effect on soybean yield, although yield decreased as temperature increased. These negative effects, however, were partly compensated for by the implementation of adaptation strategies including planting earlier in the season and changing variety. The degree of compensation was dependent on geographical area and crop, with maize adaptation delaying the negative effects of temperature on yield, compared to soybean adaptation which increased yield in China, India and Korea DPR as well as delaying the effects in the remaining countries. The results of this paper indicate the degree to which farmer-controlled adaptation strategies can alleviate the negative impacts of increasing temperature on two major crop species.
\end{abstract}

This article is part of a Special Issue on "The QUEST-GSI Project" edited by Nigel Arnell.

Gillian Rose

g.rose@reading.ac.uk

1 School of Agriculture, Policy and Development, University of Reading, Reading, UK

2 Walker Institute for Climate System Research, University of Reading, Reading, UK

3 Asia Risk Centre, Reading, UK

4 International Research Institute for Climate and Society, Columbia University, 61 Rte 9W, Palisades, NY 10964, USA 


\section{Introduction}

There is now a high level of consensus that we live in a warming world. Recent studies have found compelling evidence that global temperatures are currently rising, with scientific consensus being unequivocal that the climate system is warming (Singh and Singh, 2015). The International Panel on Climate Change 5th Assessment Report (AR5) includes projected temperature increases for the year 2100 ranging from $0.9{ }^{\circ} \mathrm{C}$ to $5.4{ }^{\circ} \mathrm{C}$ depending on emissions scenario and climate model (Burkett et al., 2014). To inform climate mitigation policy decisions, evidence is needed of the possible impacts of various degrees of climate change.

Agriculture is one of the most climate-sensitive of human activities and global warming is predicted to have a large impact on yield, even when considering the uncertainty on rainfall projections. In particular, increases in average temperature alter physiological development stages. Warmer temperatures often result in a shortening of the growing season which reduces yield (Craufurd and Wheeler 2009), whilst brief periods of extreme temperatures can reduce the number of grains per spikelet which again reduces yield (Semenov et al., 2014). Historically, it has been challenging to investigate the impact of global climate on yield because the majority of crop simulation models have either required too much input data to be feasible at a global scale, or empirical models have been used whose output can not be extrapolated beyond their current environment (for example, they have not been able to take into account the effect of increased $\mathrm{CO}_{2}$ ). Therefore, estimates of the likely impacts of climate change on crop production at a global scale were historically made by scaling-up the output of site studies (Rosenzweig and Parry 1994) or by aggregating individual studies on the basis of geography (IPCC 2007). However more recent studies including Osborne et al. (2013), Rosenzweig et al. (2013) and Arnell et al. (2014) have relied on smaller-scale studies. Such models have been used to investigate the impact of future temperatures on global or regional crop yield.

Maize is an established cereal crop that is extremely important for food security in developing countries, is the preferred staple for over 900 million poor consumers and is widely regarded as the most important staple food crop in Africa (CIMMYT, 2010). Soybean is one of the world's major and fastest-expanding oilcrops, which contributes significantly to overall human nutrition in terms of both calorie and protein intake (Thoenes 2004). It is also extremely important in the processed food and animal feed industries.

Whilst the effects of climate change on maize and soybean have been studied previously, research has tended to focus on individual regions such as the North China Plain, Europe (Iglesias et al. 2012) and sub-Saharan Africa (Cairns et al. 2013). Whilst in some regions climate change positively affected yield of maize and soybean (Deryng et al. 2014), yield decreases are reported in others (Urban et al. 2011, Ray et al. 2012). Over larger geographical areas including China and the US, the overall yield has remained stable as a result of increases in yield in one area being balanced by decreases in yield in another area (Tao et al. 2012). Globally, therefore, it is important to understand the extent to which global yield will change and where these increases and decreases may occur.

There are many methods by which farmers might adapt their practices to a changing climate. Thus it is important to also examine the impact of adaptation strategies, particularly given that it has been found that in the short term, and with little financial input, autonomous adaptation may overcome the negative effects of climate change on yield (e.g. Lobell et al. 2008). Two of the suggested adaptation strategies include altering the sowing date and changing variety (Matthews et al. 1997), and there are several studies which suggest that either 
of these strategies might help to mitigate the impact of climate at a local or regional scale (Calvino et al. 2003; de Bruin and Pederson, 2008; Andrade, 1995; Fakorede 1985; Challinor et al. 2005; Miglietta et al. 2000 and Makadho 1996).

This paper introduces a methodology for estimating global maize and soybean yield for different levels of global temperature increases. The General Large Area Model for annual crops (GLAM) is a process-based crop model, developed for large-scale global studies (Challinor et al. 2004) and has previously been used to simulate soybean (Osborne et al., 2013, Arnell et al. 2014) and maize (Greatrex 2012, Watson et al. 2014). A pattern-scaling approach is described which provides climate scenarios consistent with prescribed increases in global temperature. The impacts of climate change under a range of global temperature increases from $0.5{ }^{\circ} \mathrm{C}$ to $4{ }^{\circ} \mathrm{C}$, compared to $1961-1990$, on regional and global maize and soybean yields are examined, along with the effects of autonomous adaptation strategies (changing variety and planting date).

There are a range of crop models for maize and soybean; however, in order to establish model effectiveness at predicting yield, it is important to determine how the responses of the models differ (Bassu et al., 2014). For example, the degree to which climate change may affect yield may differ between models, with some models predicting increases in yield whilst others predict decreases. By assessing the effect of climate change on crops using a range of crop models it may be possible to gain a consensus on the direction of change (positive or negative), if not the degree of change. This study is unique in assessing the impact of climate change on not only two crops, both at the global level, but also for the major production regions representing $75 \%$ of the world's maize production and $92 \%$ of global soybean production.

\section{Methods}

\subsection{Crop modelling}

Crop yield was simulated using the General Large Area Model (GLAM) for annual crops (Challinor et al. 2004). This intermediate complexity process-based crop simulation model captures the non-linear interactions between climate and crop yield, but has few enough inputs that it can be run at spatial scales similar to global and regional climate models. Different crops are represented by changes to parameter values and by minor changes in parameterization. GLAM has been developed for a number of crops and will be used here for soybean (Osborne et al. 2013) and maize (Greatrex 2012, Watson et al. 2014). Reductions in yield are presented at $\%$ compared to the baseline data.

\subsubsection{Crop parameters}

GLAM was run using three varieties of maize and soybean, representing the two extremes of the photothermal time response and an intermediate variety. Geographic areas suitable for growing each variety were identified by a crop-suitability algorithm integrated as described by Osborne et al. (2013) with baseline and all future climate scenarios. Accumulated thermal time and precipitation values were calculated and compared against minimum thresholds related to each variety. The crop-suitability algorithm also determined the sowing date for the crop. Because the algorithm was integrated through the calendar year the derived sowing dates represent the earliest possible date - based on base temperature-for germination which might not 
be optimum for yield. For each crop variety, two GLAM simulations were performed: one run for a rain-fed crop and one for a fully-irrigated crop in which it was assumed that no soil water stress occurred.

\subsubsection{Geographic scale}

The spatial scale at which GLAM is run is dependent on the spatial scale of the input data (Challinor et al. 2004). In this study, as in Osborne et al. 2013, GLAM was applied over a global domain with input data at $0.5^{\circ}$ spatial resolution. Soil-type information was derived from the ISRIC WISE database (Batjes 2005). The $0.5^{\circ}$ resolution end-of-season yield output of GLAM was aggregated to national level using the observed area of each crop in the MIRCA2000 dataset (Portmann et al. 2010). Results are presented for the 10 major maize/ soybean producing countries which represent $84 \%$ and $94 \%$ of the world's maize and soybean production respectively (FAOSTAT 2015). For each country, total production was calculated by multiplying the 30 -year mean yield at each grid point by the cultivated area, and national yield was calculated by dividing this national production by the total cultivated area over all grid cells in each country at which GLAM was run.

\subsection{Climate scenarios}

Daily weather data was derived from the University of East Anglia Climate Research Unit (CRU) TS3 dataset of Mitchell and Jones (2005). Under baseline (1961-1990) conditions the monthly data of maximum and minimum temperature, rainfall and cloud cover were interpolated to daily time-series using the method of Gosling and Arnell (2011). Future climates were derived using a pattern-scaling approach as described in Todd et al. (2011). In essence, patternscaling is based upon the assumption that changes in local (i.e. grid box) climate are linearly proportional to global mean temperature. Therefore, spatially-explicit future climates can be created by scaling patterns of local change by the global mean temperature rise. This method has been used in previous studies to derive future climates associated with a particular future time period under a particular greenhouse gas emission scenario (e.g. 2050 A1B in Osborne et al. 2013). In this study, the method was applied to generate future climates associated with prescribed levels of global warming, specifically increases of $0.5,1.0,1.5,2.0,2.5,3.0$ and $4.0{ }^{\circ} \mathrm{C}$ from the 1961-1990 average. Daily weather data to drive the crop model was interpolated from the monthly values. Because this approach essentially decouples the climate change scenarios from the emissions scenarios there are no specific associated concentrations of $\mathrm{CO}_{2}$ for each level of warming. Instead, a range is possible given the range of climate sensitivity observed for global climate models. Because $\mathrm{CO}_{2}$ concentration is a required input for GLAM a fixed value of $532 \mathrm{ppm}$ (the level associated with the 2050s under the A1B greenhouse gas emissions scenario) was used for all future simulations. The climate model, including all relevant climate variables, used to determine the patterns of local climate change was HadCM3, a commonly-used climate model for impact assessments.

\subsection{Adaptation}

Limited autonomous adaptation was represented by altering variety and/or sowing date. Under each climate scenario as many of the three varieties of each crop as deemed suitable by the crop-suitability algorithm were simulated by GLAM. Therefore, one possible adaptation under 
changed climatic conditions would be to switch to a different variety from that which was highest-yielding under baseline climate conditions. The future climate simulations were performed both with the crop being sown on the date determined by the crop suitability algorithm under baseline conditions, and on the date determined when the algorithm was run for the future climate scenarios. Therefore, another possible adaptation could be to alter the sowing date of the crop. However, it is important to emphasise that the sowing date was never chosen to optimise yield. The yield simulation results are presented for two adaptation scenarios: No Adaptation, where sowing date and variety choice is fixed to that suitable in the baseline climate, and Adaptation, where sowing date and/or variety choice was allowed to vary from that suitable in the baseline climate.

\section{Results}

For both maize and soybean the globally-averaged yield decreased from the baseline under all levels of global warming (Fig. 1), with maize being more negatively impacted than soybean. Yield reductions for both crops were smaller under the adaptation scenario. For example, maize yield reduction in excess of $30 \%$ was simulated under the +1.5 degree warming without adaptation but occurs under the +4 degree warming when adaptation was considered. For soybean, adaptation led to a small increase in yield under the least severe global warming scenario. For both crops, with and without adaptation, yield losses in excess of $30 \%$ were simulated under the largest global warming scenario.

Considerable variation from the global impact occurred when yield changes were calculated for each country, particularly when considering the impact of adaptation. For maize, under no adaptation, large $(>30 \%)$ reductions in national average yield were simulated for all the major producing countries under the +4 degree warming, and for most under the +2 degree warming (Fig. 2). Adaptation, however, offset such reductions considerably. For France, no significant yield reduction was simulated when adaptation was permitted. However, for 6 of the top 10 countries, a yield reduction of more than $30 \%$ occurred at some point under the

Maize: No adaptation

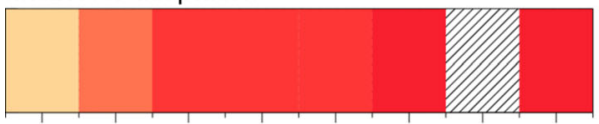

Maize: Adaptation

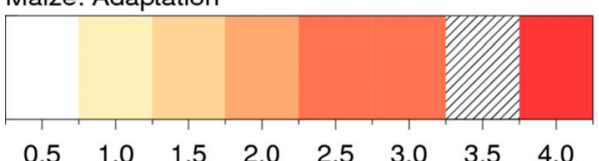

\section{Soybean: No adaptation}

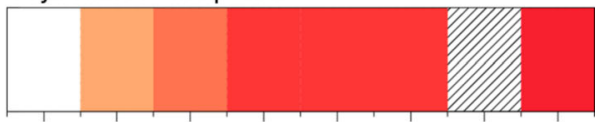

Soybean: Adaptation

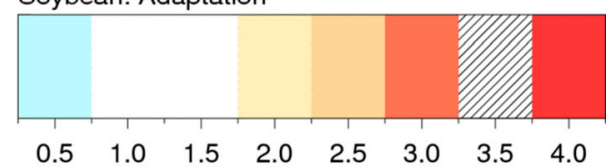

Increase in global mean temperature $\left({ }^{\circ} \mathrm{C}\right)$

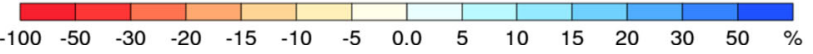

Fig 1 Change in global yield of maize and soybean under increasing global warming scenarios. White indicates the change in yield is less than the interannual variability (standard deviation) under the 1961-90 climate. Diagonal hatching indicates that impacts under +3.5 degree scenario were not simulated. Shown with and without adaptation 


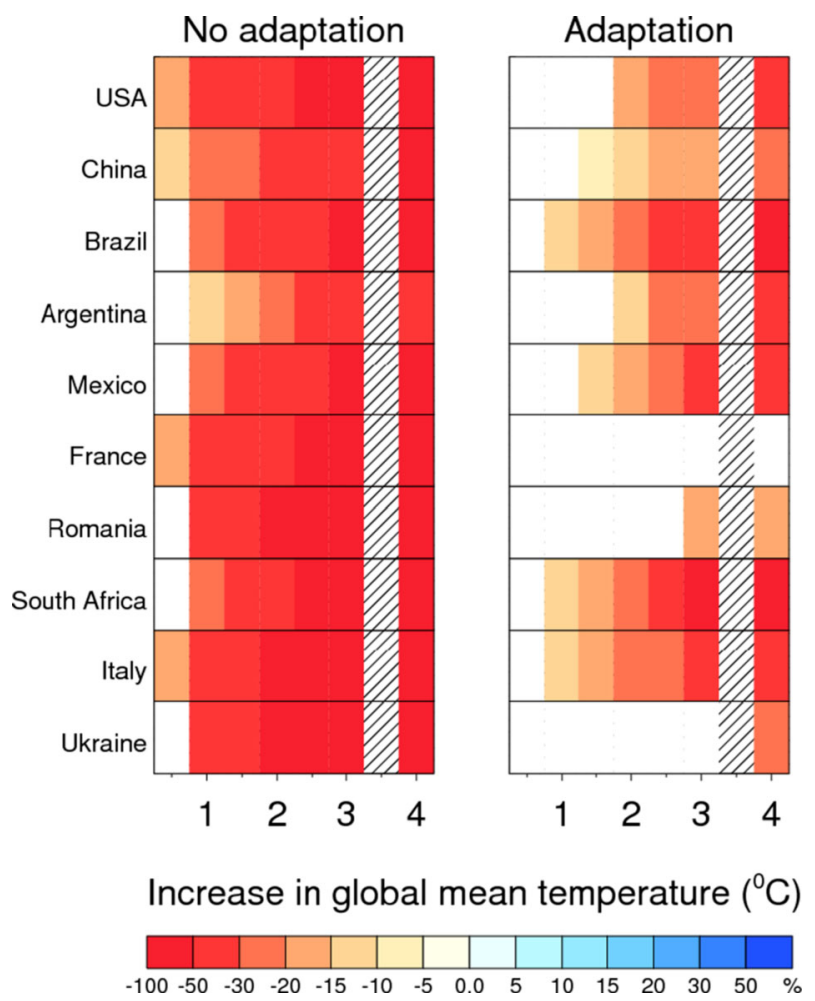

Fig 2 Change in national average yield of maize under increasing global warming scenarios for the main producing countries. White indicates the change in yield is less than one standard deviation of yield variability as simulated under the 1961-90 climate. Diagonal hatching indicates that impacts under $+3.5^{\circ} \mathrm{C}$ were not simulated. Impacts shown with and without adaptation

range of warming examined. Therefore, adaptation acted to "delay" significant reductions in yield to between +1 to +4 degrees of global warming.

Greater variations in impact between countries was simulated for soybean than for maize (Fig. 3). Without adaptation yields, 9 of the top 10 countries declined for most of the global warming scenarios. The exception to this was India, for which yields increased under global warming of greater than $3{ }^{\circ} \mathrm{C}$. For several countries, adaptation offset yield losses under climate change. In the case of Korea DPR this led to yield increasing from the baseline under moderate levels of climate change. For Paraguay and Bolivia, adaptation had little impact on the simulated yield losses under progressive climate change.

In the absence of adaptation the simulated yield reductions were closely related to the increase in growing season temperature (Figs. 4 and 5). The reduction in yield was largely explained by a shortening of the growing season under warmer conditions. Adaptation offset this via changes in planting date, which shifted the growing season to cooler periods of the year, or by switching to cultivars with greater thermal time requirements which led to a lengthening of the growing season. These mechanisms are evident in Figs. 4 and 5 as either a shift to the left (i.e. cooler growing seasons) or upwards (i.e. greater yield under the same temperature due to a longer growing season). For maize, there were four countries (USA, China, France and Italy) for which the average growing season with adaptation shifted to cooler conditions under adaptation (Fig. 4). For France, adaptation led to a cooler growing 

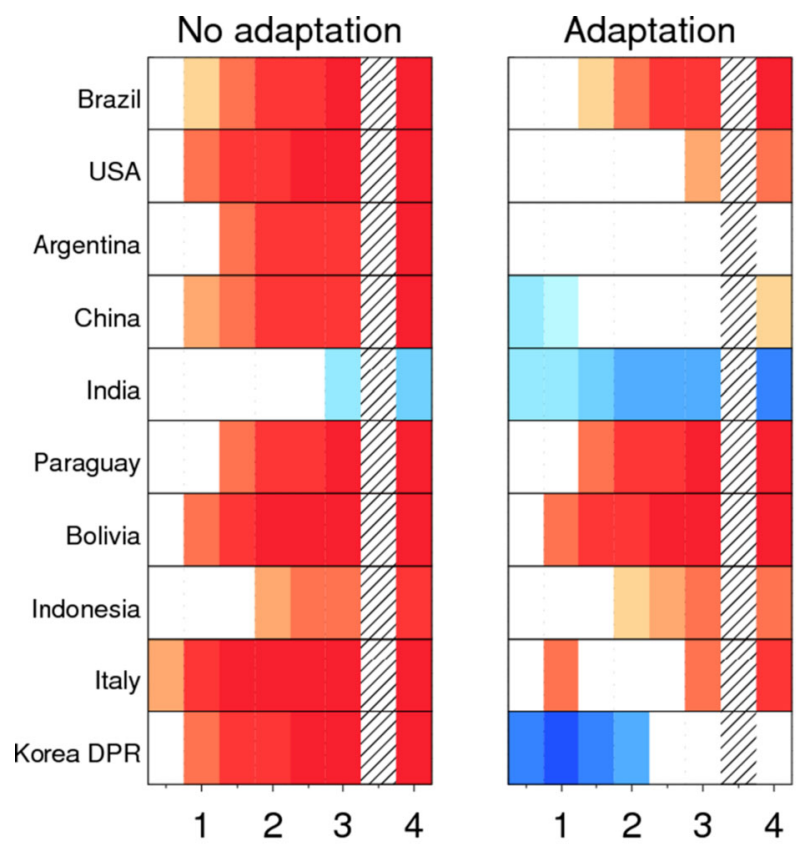

\section{Increase in global mean temperature $\left({ }^{\circ} \mathrm{C}\right)$}

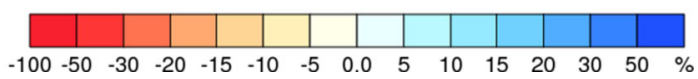

Fig 3 Change in national average yield of soybean under increasing global warming scenarios for the main producing countries. White indicates the change in yield is less than one standard deviation of yield variability as simulated under the 1961-90 climate. Diagonal hatching indicates that impacts under $+3.5{ }^{\circ} \mathrm{C}$ were not simulated. Impacts shown with and without adaptation

season than under the baseline climate. Yields were further increased by the switch in cultivars (i.e. the data points in Fig. 4 have shifted up as well as left). For the six remaining countries, the increase in yield with adaptation appears to be solely associated with the switch in cultivar, because the growing season temperature did not cool. In some instances (e.g. Argentina) there is an additional warming with adaptation. Changing the planting date of soybean decreased the growing season temperature in USA, Argentina, China, Italy and Korea DPR, yet led to warmer growing seasons in Bolivia and India (Fig. 5). For all countries, with the exception of Paraguay, changing the variety increased crop yield in response to increased temperature. Neither changing the sowing date nor the variety affected the yield of soybean grown in Paraguay.

\section{Discussion and conclusions}

Previous impact studies have shown that in mid- to high latitudes, temperature increases of 1$2{ }^{\circ} \mathrm{C}$ positively affect yield of maize, whilst temperature increases up to $5{ }^{\circ} \mathrm{C}$ had negative impacts (Parry et al., 2007). Although there was no clear correlation between latitude and temperature response in this study, yield response to climate change was dependent on country 


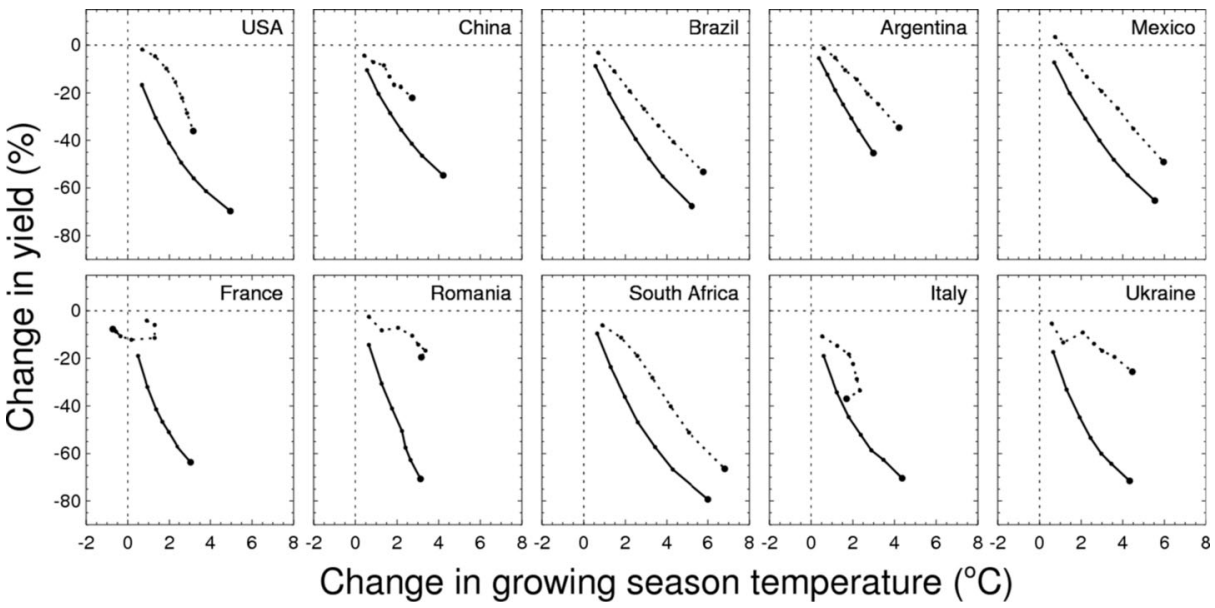

Fig 4 Relationship between change in national yield of maize and growing season temperature under increasing global warming. The large dot represents the $+4{ }^{\circ} \mathrm{C}$ scenario. No adaptation (solid), adaptation (dotted)

and crop. At the global level, Deryng et al. (2011) found that the yield of soybean and maize decreased in response to climate change, with decreases ranging from 15 to $30 \%$ and $19 \%$ $34 \%$ respectively. This is in line with the decreases found in this study, and the severity of the decrease confirms that soybean is less affected by temperature increases at the lower end of the scale compared to maize. Lobell and Gourdji (2012) predicted a yield reduction of 3-8 \% for every $1{ }^{\circ} \mathrm{C}$ increase in temperature; however, our results suggest a more severe global reaction to increasing temperature for maize with temperature increases of $0.5^{\circ} \mathrm{C}$ and $1{ }^{\circ} \mathrm{C}$ decreasing global maize yield by $10 \%$ and $20 \%$ respectively. With the addition of adaptation strategies the decrease in maize yield is in line with Lobell and Gourdji's (2012) values. At country-level there are clear differences in maize yield with temperature increases of only $0.5^{\circ} \mathrm{C}$ negatively affecting yield in USA, China, France and Italy. However, some countries are less affected, with

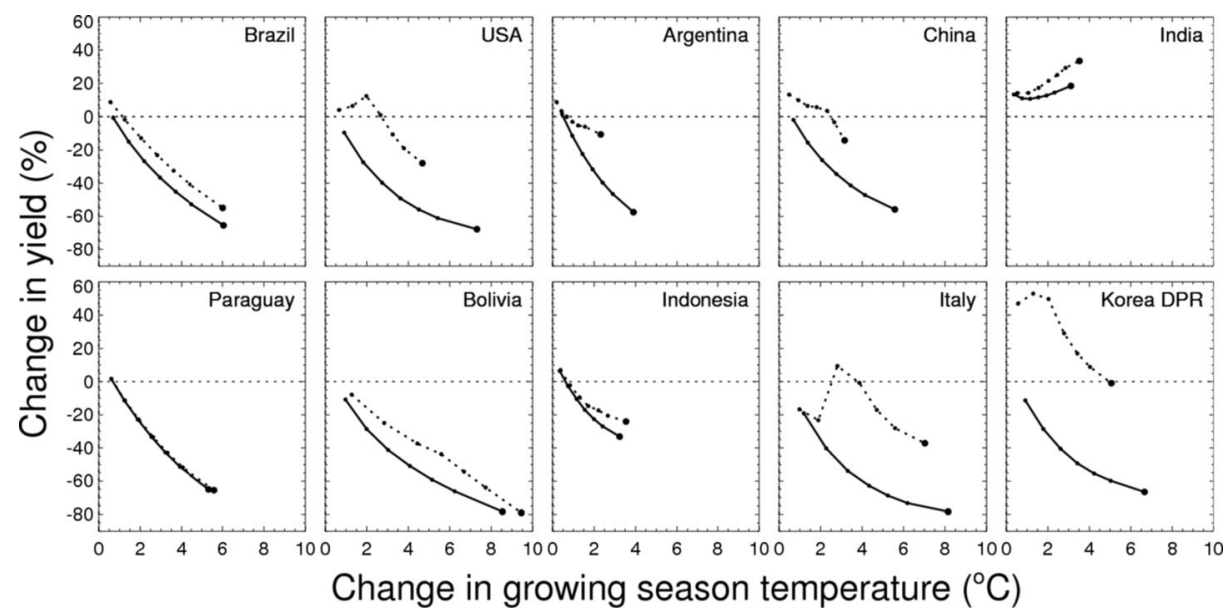

Fig 5 Relationship between change in national yield of soybean and growing season temperature under increasing global warming. The large dot represents the $+4{ }^{\circ} \mathrm{C}$ scenario. No adaptation (solid), adaptation (dotted). 
a $2{ }^{\circ} \mathrm{C}$ increase reducing maize yield by $20 \%$ compared to a $50 \%$ reduction in France, South Africa and Ukraine. Contrary to Parry et al. (2007), no increase in global yield for maize was predicted regardless of the temperature increase. Similarly, for the top 10 producing countries no increase in yield was predicted. With the inclusion of adaptation strategies the yield of maize remained unchanged in response to a $0.5{ }^{\circ} \mathrm{C}$ temperature increase within 6 of the top 10 producing countries; however, greater temperature increases resulted in reduced yield. Contrary to previous research, there was no relationship between effect of temperature and the country being classified as either tropical or temperate. Our results are however consistent with the accepted view that adaptation strategies were much more effective for maize grown in temperate regions (Porter et al., 2014).

A temperature increase of $0.5^{\circ} \mathrm{C}$ had no effect on soybean yield for the vast majority of the 10 top producing countries, although the only positive effect was predicted in India for temperature increases in excess of $3{ }^{\circ} \mathrm{C}$. This is in contrast to Deryng et al. (2014), where an overall increase in yield was predicted globally. However, variation in response was found depending on climate model. Utilisation of adaptation strategies increased yield of soybean in China, India and Korea DPR and in a further 5 countries reduced the impact of increasing temperature. This is supported by Rosenzweig et al. (2013) who also reported an increase in soybean yield in response to increasing temperature through the use of adaptation strategies. However adaptation had no effect on soybean yield in Paraguay or Bolivia. Effectiveness of adaptation strategy was found to be increased in temperature rises less than $2{ }^{\circ} \mathrm{C}$ and where water was not limited (Howden et al., 2007). Our soybean results suggest adaptation can be effective at temperatures up to $4{ }^{\circ} \mathrm{C}$ but that response is country-dependent.

Adaptation strategies investigated included planting earlier in the season or changing crop variety, and results suggest these strategies resulted in a lower growing season temperature as the growing season started earlier in the year. For maize and soybean adaptation strategies yield decreases are at the lower end of the temperature scale and for soybean in specific geographical regions they resulted in yield increases. Crop development is directly related to temperature, therefore by sowing earlier in the season when temperatures are cooler, the rate of crop development will decrease, which allows more time for grain/pod filling and would therefore be expected to increase yield (Craufurd and Wheeler 2009).

Crop models are generally run on relatively small scales, with input data reflecting local agricultural practices, such as planting date, and meteorological inputs. In this and other recent studies, crop models have been applied over global domains to determine the impact of climate change on crop productivity at national, regional and global levels. Such application necessitates the making of simplifying assumptions regarding crop characteristics (such as variations in thermal time requirement) and management (such as planting date). Therefore, the results of this study should not be viewed as providing the evidence for local adaptation decisions but rather the potential impacts at aggregate scale of a range of global-warming scenarios. Adaptation strategies were included as some level of autonomous adaptation should be expected under changing environmental conditions.

The ability to examine the impacts of prescribed levels of global warming was permitted by the utilisation of a pattern-scaling technique for creating the climate scenarios. Pattern-scaling is reliant upon the linear response of local climate to global warming. The existence of such relationships has since been disputed (Cabre et al., 2010) but Mitchell (2003) argues that the errors are relatively small - globally $0.1^{\circ} \mathrm{C}$ or $0.02 \mathrm{~mm} /$ day and not exceeding $0.3{ }^{\circ} \mathrm{C}$ or $0.3 \mathrm{~mm} /$ day for an individual grid box. A more specific caveat of the approach for crop impact studies is the de-coupling of atmospheric concentration of $\mathrm{CO}_{2}$ from the global warming response. 
The results of this modelling study suggest that even small $\left(0.5^{\circ} \mathrm{C}\right)$ increases in temperature will have negative impacts on maize yield, the severity of which will increase with increasing temperature. Use of farmer-instigated adaptation strategies may alleviate the effects of a $0.5^{\circ} \mathrm{C}$ warming; however, temperatures greater than $1{ }^{\circ} \mathrm{C}$ will negatively affect yield. Negative impacts of temperature are not demonstrated globally in soybean until warming increases to $1{ }^{\circ} \mathrm{C}$, although this effect is country-specific, with 5 of the top 10 producing countries having reduced yield in response to $0.5^{\circ} \mathrm{C}$ increases in temperature. Adaptation can promote yield at small temperature increases, and can off-set the negative impact until the temperature increases globally to $2{ }^{\circ} \mathrm{C}$, however this response is also country-specific, with France demonstrating no decrease in yield under a $4{ }^{\circ} \mathrm{C}$ increase in temperature, whilst Brazil may demonstrate a decrease after a $1{ }^{\circ} \mathrm{C}$ temperature increase.

Acknowledgments We would like to acknowledge the support of the Natural Environment Research Council for funding for the QUEST-GSI project.

Open Access This article is distributed under the terms of the Creative Commons Attribution 4.0 International License (http://creativecommons.org/licenses/by/4.0/), which permits unrestricted use, distribution, and reproduction in any medium, provided you give appropriate credit to the original author(s) and the source, provide a link to the Creative Commons license, and indicate if changes were made.

\section{References}

Andrade FH (1995) Analysis of growth and yield of maize, sunflower and soybean grown at balcarce, Argentina. Fields Crops Res 41:1-12

Arnell NW, Brown S, Gosling SN, Gottschalke P, Hinkel J, Huntingford C, Lloyd-Hughes B, Lowe JA, Nicholls RJ, Osborn TJ, Osborne TM, Rose GA, Smith P, Wheeler TR, Zelazowski P (2014) The impacts of climate change across the globe: a multi-sectoral assessment. Clim Chang. doi:10.1007/s10584-014-1281-2

Bassu S et al. (2014) How do various maize crop models vary in their response to climate change factors? Global Change Biol. doi:10.1111/gcb.12520

Batjes NH (2005) ISRIC WISE global data set of derived soil properties on a 0.5 by 0.5 degree grid (Version 3.0). Report 2005/2008, ISRIC-World Soil Information, Wageningen (with data set) www.isric.org/UK/About+ Soils/Soil+data/Geographic+data/Global/WISE+spatial+ver.+3.0.htm

Burkett VR, Suarez AG, Conde C, Mukerji R, Prather MJ, St. Clair AL, Yohe GW (2014) Point of departure. In: Climate Change 2014: Impacts, Adaptation and Vulnerabilitiy. Part A: Global and sectoral aspects. Contribution of Working Group II to the Fifth Assessment Report of the Intergovernmental Panel on Climate Change [ Field CB, Barros VR, Dokken DJ, Mach KJ, Mastrandrea MD, Bilir TE, Chatterjee M, Ebi KL, Estrada YO, Genova RC, Girma B, Kissel ES, Levy AN, MacCracken S, Mastrandrea PR, White LL (eds)] Cambridge University Press, New York, pp 169-194

Cabre MF, Solman SA, Nunez MN (2010) Creating regional climate change scenarios over southern South America for the $220 \mathrm{~s}$ and 2050 's using the pattern scaling technique: validity and limitations. Clim Chang 98:449-469

Cairns JE, Hellin J, Sonder K, Araus JL, MacRobert JF, Thierfelder J, Prasanna BM (2013). Adapting maize production to climate change in Sub-Saharan Africa. Journal of Food Security 5:345-360

Calvino PA, Sadras VO, Andrade FH (2003) Development, growth and yield of late sown soybean in southern pampas. Eur J Agro 19:265-275

Challinor AJ, Wheeler TR, Craufurd PQ, Slingo JM, Grimes DIF (2004) Design and optimisation of a large-area process-based model for annual crops. Agric For Met 144:99-120

Challinor AJ, Wheeler TR, Slingo GM, Hemming D (2005) Quantification of physical and biochemical uncertainty in the simulation of the yield of a tropical crop using present day and doubled $\mathrm{CO} 2$ climates. Phil Trans R Soc 1463:2085-2094. doi:10.1098/rstb.2005.1740

Craufurd PQ, Wheeler TR (2009) Climate change and flowering time of annual crops. J Exp Bot 60:2529-2539

CIMMYT (2010) MAIZE - global alliance for improving food security and the livelihoods of the resource-poor in the developing world, edited. CYMMIT, Proposal submitted by CIMMYT and IITA to the CGIAR Consortium Board 
Deryng D, Conway D, Ramankutty N, Price J, Warren R (2014) Global crop yield responses to extremem heat stress under multiple climate change future. Environ Res Lett. doi:10.1088/1748-9326/9/3/034011

Deryng D, Sacks WJ, Barford CC, Ramankutty N (2011) Simulating the effects of climate and agricultural management practices on global crop yield. Glob Biogeochem Cycles 25:2. doi:10.1029/2009GB003765

Fakorede MAB (1985) Response of maize to planting dates in a tropical rainforest location. Exp Agric 21:19-30

FAOSTAT (2015) Crop Prod Stat Available at http://faostat3.fao.org/home/E [accessed June 2015]

Greatrex H (2012) The application of seasonal rainfall forecasts and satellite rainfall estimates to seasonal crop yield forecasting for Africa. $\mathrm{PhD}$ thesis, University of Reading

Gosling SN, Arnell NW (2011) Simulating current global river runoff with a global hydrological model: model revisions, validation and sensitivity analysis. Hydrol Process 25:1129-1145

Howden SM, Soussana J, Tubiello FN, Chhetri N, Dunlop M, Meinke H (2007) Adapting agriculture to climate change. Proc Natl Acad Sci U S A 104:19691-19696

Iglesias A, Garrote L, Quiroga S, Moneo M (2012) A regional comparison of the effects of climate change on agricultural crops in Europe. Clim Chang. doi:10.1007/s10584-011-0338-8

IPCC (2007) Climate Change 2007: Impacts, Adaptation and Vulnerability. Contribution of Working Group II to the Fourth Assessment. Report of the Intergovernmental Panel on Climate Change, Parry ML,Canziani OF, Palutikof JP, van der Linden PJ, Hanson CE (eds) Cambridge University Press, UK, 976pp.

Lobell DB, Burke MB, Tebaldi C, Mastrandrea MD, Falcon WP, Naylor RL (2008) Prioritizing climate change adaptation needs for food security in 2030. Sci 319:607-610

Lobell DB, Gourdji M (2012) The influence of climate change on global crop productivity. Plant Physiol 160:1686-1697

Makadho JM (1996) Potential effects of climate change on corm production in Zimbabwe. Clim Res 6:147-151

Matthews RB, Kropff MJ, Horie T, Bachelet D (1997) Simulating the impact of climate change on rice production in Asia and evaluating options for adaptation. Agric Syst 54:399-425

Miglietta F, Bindi M, Vaccari FP, Schapendonk AHCM, Wolf J, Butterfield RE (2000) Crop ecosystem responses to climate change: root and tuberous crops. In: Reddy KR, Hodges HF (eds) Climate change and global crop productivity. CABI Publishing, OXON, UK

Mitchell TD (2003) Pattern scaling: an examination of the accuracy of the technique for describing future climates. Clim Chang 60:217-242

Mitchell TD, Jones PD (2005) An improved method of constructing a database of monthly climate observations and associated high-resolution grids. Int J Clim 25:693-712

Osborne TM, Rose GA, Wheeler TR (2013) Variation in the global-scale impacts of climate change on crop productivity due to climate model uncertainty and adaptation. Ag For Meteorol 170:183-194

Parry ML, Canziani OF, Palutikof JP, van der Linden PJ, Hanson CD (eds) (2007) Contribution of working group II to the fourth assessment report of the intergovernmental panel on climate change, 2007. Cambridge University Press, Cambridge

Porter JR, Xie L, Challinor AJ, Cochrane K, Howden SM, Eqbal MM, Lobell DB, Travasso MI (2014) Food security and food production systems. In: Climate Change 2014: Impacts, Adaptation and Vulnerability. Part A: Global and Sectoral Aspects. Contribution of Working Group II to the Fifth Assessment Report of the Intergovernmental Panel on Climate Change [Field CB, Barros VR, Dokken DJ, March KJ, Mastrandrea MD, Bilir TE, Chatterjee M, Ebi KL, Estrada YO, Genova RC, Girma B, Kissel ES, Levy An, MacCracken S, Mastrandrea PR, White LL (eds)]. Cambridge University Press, United Kingdom pp485-533

Portmann F, Siebert S, Doll P (2010) Global monthly irrigated and rainfed crop areas around the year 2000: a new high resolution data set for agricultural and hydrological modelling. Glob Biogeochem Cycles 24: GB1011. doi:10.1029/2009GB003435

Ray DK, Ramankutty N, Meuller ND, West PC, Foley JA (2012) Recent patterns of crop yield growth and stagnation. Nat Commun. doi:10.1038/ncomms2296

Rosenzweig C, Elliott J, Deryng D, Ruane AC, Muller C, Arneth A, Boote KJ, Folberth C, Glotter M, Khabarov N, Neumann K, Piontek F, Pugh TAM, Schmid E, El S, Yang H, Jones JW (2013) Assessing agricultural risks of climate change in the 21st century in a global gridded crop model comparison. PNAS doi. doi:10. 1073/pnas. 1222463110

Rosenzweig C, Parry ML (1994) Potential impact of climate change on world food supply. Nature 367:133-138. doi:10.1016/j.jcs.2014.01.006

Semenov MA, Stratonovitch P, Alghabari F, Gooding MJ (2014) Adapting whet in Europe for climate change. J Cereal Sci

Singh MK, Singh BR (2015) Observation and temperature changes: warming of the climate system and future global warming in 21st century. J Phys Sci. doi:10.18090/samriddhi.v5i2.1531

Tao F, Zhang Z, Zhang S, Zhu Z, Shi W (2012) Response of crop yields to climate trends since 1980 in China. Clim Res. doi:10.3354/cr01131

Thoenes P (2004) The role of soybeans in fighting world hunger. Paper presented by the FAO at the VIIth World Soybean Research Conference held in Foz do Iguassu, Brazil, 1-5 March 2004 
Todd MC, Taylor RG, Osborn TJ, Kingston DG, Arnell NW, Gosling SN (2011) Uncertainty in climate change impacts on basin-scale freshwater resources - preface to the special issue: the QUEST-GSI methodology and synthesis of results. Hydrol Earth Syst Sci 15:1035-1046

Urban D, Roberts MJ, Schlenker W, Lobell DB (2011) Projected temperature changes indicate significant increase in interannual variability of US maize yields. Clim Chang 112:525-533

Watson J, Challinor AJ, Fricker TE, Ferro CAT (2014) Comparing the effects of calibration and climate errors on a statistical crop model and a process-based crop model. Climatic Change doi. doi:10.1007/s10584-0141264-3 